\title{
I Kongres Mediewistów Polskich - Toruń, 16 - 18 września 2002 r.
}

Campus Uniwersytetu Mikołaja Kopernika gościł w dniach 16 - 18 września licznie zgromadzonych mediewistów reprezentujących polskie środowiska naukowe: uniwersytety i inne wyższe uczelnie, PAN, PAU oraz instytuty badawcze. Wśród różnorodnych tematów, które były przedmiotem obrad, takich jak: „Ustrój społeczny Polski średniowiecznej” (sesje tematyczne: „Ludzie Kościoła”, „Początki państw późnośredniowiecznych”, „Przestrzeń i społeczeństwo miasta średniowiecznego”); „Mechanizmy władzy w późnym średniowieczu” (sesje tematyczne: „Elity możnowładeze w Polsce późnego średniowiecza”, „Horyzont geograficzny Europy Środkowo-Wschodniej”, „Między nadawcą a odbiorca - w kręgu form średniowiecznej komunikacji społecznej”) oraz forum dyskusyjnego pt. „Mediewistyka - jeden czy wiele warsztatów", na uwagę historyków wychowania zasługuje szczególnie tematyka obrad sympozjum pt. „Świat średniowiecznego uniwersytetu”.

Prowadzącym obrady sekcji był Krzysztof Ożóg (Kraków), natomiast z referatami wystapili uczeni spoglądający na fenomen średniowiecznego uniwersytetu $\mathrm{z}$ punktu widzenia różnych dyscyplin humanistyki. Pierwszy zabrał głos Krzysztof Stopka (Kraków), a tematem jego wystapienia był „Uniwersytet w rzeczywistości politycznej późnośredniowiecznej Europy”. Krakowski uczony zauważył na wstępie, że prawo kreowania uniwersytetów należało początkowo do papieży i cesarzy, a następnie rozszerzyło się na innych władców terytorialnych, przy czym władza duchowna wykazywała zdecydowanie większą aktywność. Najstarszy uniwersytet (Bolonia) otrzymał zgodę cesarska, natomiast najstarsza fundacja papieska była Lizbona (1291). Papiestwo zachowało do końca średniowiecza monopol w funkcjonowaniu uniwersytetów - bez zgody Rzymu (Awinionu) uczelnie nie mogly zakładać wydziałów teologicznych, które stanowiły o randze uniwersytetów. Uczelnie aktywnie uczestniczyły w życiu politycznym Europy, wysyłając swych przedstawicieli na wszelkiego rodzaju uroczystości, zjazdy władców, sobory itp. Dopiero pod koniec średniowiecza uniwersytety straciły wiele ze swej autonomii na rzecz polityki państw narodowych, wzrósł wówczas nadzór państwa na działalnością władz uczelni - odtąd wzorem stał się uniwersytet służący własnemu krajowi. Państwo narzucało kierunki nauczania, czas nauki itp. a tym samym zanikła średniowieczna idea uniwersyteckiej wolności.

Kolejny referat poświęcony został uczoności uniwersyteckiej. Lucyna Nowak (Biblioteka Jagiellońska) omówiła recepcję pism Arystotelesa na uniwersytecie krakowskim. Mówczyni przedstawiła różnorodne źródła poznawania dzieł greckiego filozofa: poprzez tłumaczenia Boecjusza, Jakuba z Wenecji, Roberta Grosseteste, jak i wzbogacone przez komentarze Aworroesa $i$ Awicenny tłumaczenia arabskie. W XII w. pisma Arystotelesa weszły na stałe do kanonu uniwersyteckiego. W drugiej części referatu L. Nowak przedstawiła drogi recepcji Arystotelesa w Polsce. Pierwsze księgi zawierające filozofię Stagirczyka trafiły do naszego kraju dzięki Witelonowi, Iwo Odrowążowi, dominikanom studiujacym na uczelniach północnowłoskich. W 1265 r. utworzono w Bolonii nację polska, której członkowie przywozili książki stanowiące następnie podstawę zbiorów uniwersyteckich. Najstarsze księgi przechowywane w zbiorach Biblioteki Jagiellońskiej pochodzą z XIII w., a zostały skopiowane we Francji, Niemczech, Włoszech, Anglii i w Czechach.

Mikołaj Olszewski (Warszawa) w przyjętym z dużym zainteresowaniem referacie przedstawił następnie życie naukowe i intelektualne średniowiecznych społeczności akademickich, które toczyło się pod znakiem sporów doktrynalnych, dotyczących głównie zagadnień teologicznych. Podstawowym problemem było pytanie czy teologia uniwersytecka jest nauka teoretyczną czy praktyczną? Referent omówił różne aspekty tego toczącego się przez kilkaset lat gorącego sporu, którego poczatkiem była fuzja tradycji augustiańskiej, mówiącej, że celem teologii jest miłość (caritas) i stan poznawczy (visio) z Arystotelesem, twierdzącym, że wszelka nauka ma dwa aspekty: teoreticos i practicos. Święty Bonawentura uważał, że teologia jest praktyczna, ale ma składowa teoretyczna i część pośrednia. W połowie XIII w. Tomasz z Akwinu w „Summie teologii” uznał, że przedmiotem teologii jest Bóg, 
a nauka ta nie jest nauka praktyczna, bo nie można oddziaływać na Boga. To właśnie stwierdzenie rozpoczęło spór $-z$ Tomaszem polemizowało wielu autorów: Idzi Rzymianin sądził, że głównym celem teologii jest caritas, a zatem jest to nauka afektywna (nie praktyczna), z kolei Gotfryd z Fontain uważał, że teologia nie ma jednego przedmiotu - podobny pogląd podzielało środowisko franciszkańskje: Jan Duns Szkot sformułował tezę, że przedmiotem nauki jest Bóg, ale jest ona praktyczna. Wilhelm Ockham przedstawił natomiast pogląd, że twierdzenia teologiczne wyrażone są w postaci pewnych zdań, które sa teoretyczne i praktyczne, zatem teologia jako zbiór takich zdań ma obie postacie. Grzegorz z Rimini próbował wyjść z impasu twierdzac, że Ockham miał rację, ale zdania te tworza system o strukturze piramidy, konkludując, że teologia jest praktyczna, mówi ona bowiem jak należy kochać Boga.

Sesję zakończył referat Andrzeja Wlodarka (Toruń), który zają się przestrzenia architektoniczną średniowiecznego uniwersytetu krakowskiego. Uniwersytet był instytucją organicznie związaną z miastem i poprzez swoje instytucje wpisywał się w przestrzeń miasta. Referat omawiał sposoby nabywania przez Akademię Krakowską kolejnych gmachów, metody ich adaptacji na potrzeby dydaktyczne. A. Włodarek skrupulatnie przedstawił dzieje poszczególnych gmachów uniwersyteckich.

Przestawione przez referentów zagadnienia doskonale ukazuja różnorodność pytań badawczych stojących przed uczonymi wielu specjalności, zgłębiajacymi wspaniałą przeszłość uniwersytetów i ludzi je tworzacych.

Krzysztof Ratajczak

\section{Krajowa Konferencja Naukowa „Przeszłość polskiej kultury fizycznej”}

W dniach 16 - 18 września 2002 roku w Krakowie odbyła się II Krajowa Konferencja Naukowa pt.: „Przeszłość polskiej kultury fizycznej”. Konferencja organizowana była w ramach Jubileuszu 75-lecia Akademii Wychowania Fizycznego.

Jej organizatorami był Instytut Nauk Humanistycznych Akademii Wychowania Fizycznego oraz Zakład Historii Oświaty i Kultury Uniwersytetu Jagiellońskiego.

Referenci sesji reprezentowali następujace ośrodki: Uniwersytet Jagielloński, AWF Warszawa, AWF Kraków, AP Kraków, AWF Wrocław, AWF Poznań, Uniwersytet im. Adama Mickiewicza w Poznaniu, Uniwersytet Rzeszowski, AWF Katowice, AWF Gorzów Wlkp., WSP Częstochowa.

Przybyłych gości powitał i konferencję otworzył prof. dr hab. Janusz Zdebski. Inauguracyjny wykład wygłosit Prorektor prof. dr hab. Ryszard Winiarski.

Wystąpienia przedpołudniowe pierwszego dnia obrad, prowadzone przez prof. Janusza Zdebskiego, poświęcone były roli Krakowa w życiu społeczeństwa polskiego na przełomie XIX i XX wieku oraz dziejom krakowskiej Akademii Wychowania Fizycznego.

Z uwagi na duże swobody autonomiczne Galicja stała się terenem. gdzie szczególnie pielęgnowano polskie tradycje i jubileusze. Kraków stał się miejscem pielgrzymek narodowych oraz narodowego pąnictwa. Obchodzono tu uroczystości, których nie woIno było celebrować w innych zaborach. Krakowskie instytucje akademickie skupiały i spełniały wszystkie funkcje naukowe pozostałych polskich dzielnic. Uniwersytet stał się miejscem zjazdów oraz ośrodkiem badań naukowych. Prezentujac ówczesny obraz Krakowa oraz podkreślając jego znaczenie prof. dr hab. Julian Dybiec nazwał go „Polskimi Atenami”.

W swoim wykładzie prof. dr hab. Kazimierz Toporowicz zwrócił uwagę, że przyjęty stereotypowo rok 1927 nie stanowi rzeczywistego poczatku uniwersyteckiej idei wychowania fizycznego. $Z$ dokumentów źródłowych wynika, że idea ta zrodziła się dużo wcześniej. Kurs Naukowy oraz Studium Wychowania Fizycznego były pionierskimi w tym względzie. Okres, na który przypada początek 